David Nott Foundation

Cite this as: $B M J 2022 ; 376: 0605$ http://dx.doi.org/10.1136/bmj.0605 Published: 07 March 2022

\section{Ukraine invasion: Why I fear for Ukraine's healthcare workers}

\section{Healthcare workers must be allowed to move freely and humanitarian agencies granted access to those in need of aid, argues Elly Nott}

\section{Elly Nott co-founder}

For anyone who has paid attention to the Syrian conflict over the past 11 years, there was a grim predictability about the news that Russian cluster munitions had killed civilians, injured healthcare workers, and damaged a hospital and an ambulance on the first day of the Russian invasion of Ukraine. ${ }^{1}$

Human Rights Watch has documented the use of cluster munitions-weapons that scatter large numbers of explosive submunitions over a wide area-by Russian and Syrian forces in Idlib governorate, Syria. ${ }^{2}$ They have described how the "nature and scale of the airstrikes and ground attacks on civilians committed by the Syrian-Russian alliance during the Idlib offensive in 2019 to 2020 may amount to crimes against humanity."3

Now, Russia appears to be pursuing military tactics honed in Syria in its assault on Ukraine, including indiscriminate bombing and besiegement of civilian areas, use of paramilitary forces, and disinformation campaigns. The assault on health has been one of the most striking features of the Syrian conflict. One of the most authoritative investigations was the Lancet-American University of Beirut Commission on Syria, which used the term "weaponisation" to describe the strategy of violently depriving people of the healthcare they need at the cost of hundreds of healthcare workers being killed, incarcerated, or tortured and scores of healthcare facilities being attacked. $^{4}$

A UN General Assembly Human Rights Council Report in 2015 spoke of Syrian government forces instrumentalising the basic needs of civilians, including access to medical care, "as part of a military strategy to... punish those perceived to be affiliated with armed groups."5

In this assault on health, the Syrian regime has been ably assisted by the Russian government. Despite International Humanitarian Law protecting medical personnel and facilities in conflict, multiple investigations by Human Rights Watch, Physicians for Human Rights, and the New York Times have found that the Russian Air Force has repeatedly bombed hospitals in Syria. ${ }^{6-8}$ Physicians for Human Rights estimate that more than 923 healthcare workers have been killed directly during the conflict, with more than $90 \%$ of them killed by the Syrian government and its allies-including Russia. ${ }^{9}$

In 2020, Russia abandoned any pretext of respect for the Geneva Conventions when it quit the UN deconfliction arrangement, which sought to protect hospitals and the distribution of humanitarian aid. ${ }^{10}$

In response to the onslaught, hospitals in Syria moved underground and sought to keep their locations secret. Yet, despite the attempts to silence healthcare workers, they have been among the most outspoken and authoritative voices in Syria's war, articulating human rights norms and pricking the conscience of the world. Amani Ballour's hospital in Eastern Ghouta was shown in the film The Cave and Waad El-Kateab's meticulous chronicling of the Syrian Revolution and siege of eastern Aleppo was depicted in For Sama. Syrian healthcare workers have borne witness to some of the worst atrocities in Syria, and have spoken out about these and reminded us of norms on human rights and justice.

In Ukraine, healthcare workers are also moving their vital work underground. Maternity wards and paediatric units have been forced into underground bomb shelters for safety, including children being treated for leukaemia at the biggest hospital in the capital, Kyiv. Critical supplies including oxygen, insulin, and cancer treatments are in short supply.

In Syria, the regime has successfully manipulated the flow of humanitarian aid to opposition-controlled areas. The need to create grassroots health systems sustained by cross-border activity was not a result of opposition-controlled areas being geographically hard to reach or having access denied by armed groups, but because access was restricted by the government of Syria. This situation led the UN Security Council (UNSC) to pass Resolutions firstly calling on all parties in the Syrian conflict to permit free access to humanitarian aid (22 February 2014 UNSCR 2139) and then authorising humanitarian aid to be supplied via four border crossings not controlled by the Syrian government, generally to supply rebel-controlled territory (14 July 2014 UNSCR 2165).

If Russia is successful in occupying Ukraine, one concern is that they will seek to manipulate humanitarian aid in the same way Assad has in Syria. Healthcare workers must be allowed to move freely and humanitarian agencies granted access to those in need of aid.

Healthcare is a significant force, especially in conflict. Not only because it cares for wounded combatants but because, as Neve Gordon wrote: "it is essential for sustaining the social body... it enables society to continue functioning before, during, and after wartime."11

As Putin's forces pursue their objectives in Ukraine, as they have for the past 11 years in Syria, Ukraine has become a very dangerous place to be a healthcare worker.

\section{Competing interests: None declared}

Provenance and peer review: commissioned, not peer reviewed 


\section{OPINION}

1 https://www.hrw.org/news/2022/02/25/ukraine-russian-cluster-munition-hits-hospital\#

2 https://www.icrc.org/en/doc/resources/documents/legal-fact-sheet/cluster-munitions-factsheet230710.htm

3 https://www.justice.gov/eoir/page/file/1327676/download, p.131.

4 Fouad FM, Sparrow A, Tarakji A, etal. Health workers and the weaponisation of health care in Syria: a preliminary inquiry for The Lancet-American University of Beirut Commission on Syria. Lancet 2017;390:2516-26. doi: 10.1016/S0140-6736(17)30741-9. pmid: 28314568

5 Report of the Independent International Commission of Inquiry on the Syrian Arab Republic: 60

6 https://www.hrw.org/report/2020/10/15/targeting-life-idlib/syrian-and-russian-strikes-civilianinfrastructure

7 https://syriamap.phr.org/\#/en

8 https://www.nytimes.com/2019/10/13/world/middleeast/russia-bombing-syrian-hospitals.html

9 https://phr.org/our-work/resources/medical-personnel-are-targeted-in-syria/

10 https://www.reuters.com/article/syria-security-russia-un-idUSL1N2E2122

11 Gordon N. The Moral Norm, the Law, and the Limits of Protection for Wartime Medical Units in: Bseiso, Jehan; Hofman, Michiel; Whittal J. Eds. (2021), Everybody's War. Oxford University Press; 2021. 